\title{
Pemanfaatan molase sebagai sumber karbon alternatif dalam pembuatan nata de coco
}

Utilization of molasses as alternative carbon sources in making nata de coco

\author{
Budi Santosa $^{1}$, Wirawan ${ }^{1}$, Rikawanto Eko Muljawan ${ }^{2}$ \\ ${ }^{1)}$ Program Studi Teknologi Industri Pertanian, Fakultas Pertanian, Universitas Tribbuwana \\ Tunggadewi Malang \\ ${ }^{2)}$ Program Studi Agribisnis, Fakultas Pertanian, Universitas Tribhuwana Tunggadewi Malang \\ email: budi.unitri@gmail.com
}

Informasi Artikel:

Dikirim: 30/08/2019; ditinjau: 31/08/2019; disetujui: 30/09/2019

\begin{abstract}
In the process, nata de coco is formed from the decomposition of carbon sources by Acetobacter xylinum by fermentation, converted into cellulose which was originally a thin membrane and then increasingly thickened forming nata pellicles. Making nata de coco has been utilizing carbon sources from sugar. The price of sugar in its development is increasingly expensive so it is necessary to find alternative carbon sources that are cheap one of which is molasses. The research aims to obtain the right concentration of molasses in producing high quality nata de coco. The research design used was a single complete Randomized Design (CRD), as a factor, namely the concentration of molasses consisting of 6 levels $M 1=1 \%, M 2=1.5 \%, M 3=2 \%, M 4=$ $2.5 \%, M 5=3 \%, M 6=3.5 \%$. The treatment was repeated 4 times so that the samples obtained were 24 samples. The results showed that molasses could be used as an alternative carbon source in making nata de coco. The concentration of molasses that produce quality nata de coco is $3 \%$ with a thickness of $1.98 \mathrm{~cm}$, weight of 275 grams and crude fiber $2.95 \%$. But the color of nata de coco produced is murky brown. Thus molasses can be used as a carbon source instead of sugar in the manufacture of nata de coco.
\end{abstract}

Keywords: carbon source, molasses, nata de coco

\begin{abstract}
ABSTRAK
Nata de coco dalam prosesnya terbentuk dari penguraian sumber karbon oleh Acetobacter xylinum melalui fermentasi, diubah menjadi selulosa yang awalnya berupa membran tipis kemudian semakin lama semakin menebal membentuk pelikel nata.Pembuatan nata de coco selama ini memanfaatkan sumber karbon dari gula pasir.Harga gula pasir dalam perkembangannya semakin mahalsehingga perlu dicari sumber karbon alternatif yang harganya murah salah satunya yaitu molase. Penelitian bertujuan untuk mendapatkan konsentrasi molase yang tepat dalam menghasilkan nata de coco yang berkualitas. Rancangan penelitian yang digunakan yaitu Rancangan Acak Lengkap (RAL) faktor tunggal, sebagai faktornya yaitu konsentrasi molase terdiri atas 6 level M1 $=1 \%, \mathrm{M} 2=1,5 \%, \mathrm{M} 3=2 \%, \mathrm{M} 4=2,5 \%, \mathrm{M} 5=3 \%, \mathrm{M} 6=3,5 \%$. Perlakuan diulang sebanyak 4 kali sehingga sampel yang diperoleh sebanyak 24 sampel. Hasil penelitian menunjukkan molase dapat digunakan sebagai sumber karbon alternatif dalam pembuatan nata de coco. Konsentrasi molase yang menghasilkan nata de coco berkualitas yaitu $3 \%$ dengan ketebalan $1,98 \mathrm{~cm}$, bobot 275 gram dan serat kasar 2,95\%.
\end{abstract}


Namun warna nata de coco yang dihasilkan keruh coklat.Dengan demikian molase dapat digunakan sebagai sumber karbon pengganti gula pasir dalam pembuatan nata de coco.

Kata kunci : sumber karbon, molase, nata de coco

\section{PENDAHULUAN}

Nata de coco diproses melalui fermentasi dalam media air kelapa menggunakan Acetobacter xylinum (Santosa et al., 2012). Produk minuman ini memiliki ketebalan lebih kurang 2 centimeter berwarna putih dan kenyal (Martins et al., 2009; Lin et al., 2013; Hirayama et al., 2013). Kandungan terbesar di dalam nata de coco berupa serat selulosa yang dinamakan selulosa bakteri (Hidayat et al., 2006). Selulosa bakteri pemanfaatannya tidak hanya di bidang pangan tapi juga non pangan sepertiuntuk minuman, film pengemas pangan (plastik biodegradable), pembuatan kertas, membran ultrafiltrasi, bidang kedokteran, industri non pangan lain dan sebagainya (Iskandar dkk., 2010; Jung et al., 2010; Backdahl et al., 2011; Jiazhi et al., 2011; Pratomo dan Rohaeti, 2011; Syamsu et al., 2014; Bhanthumnavin et al., 2016).

Produk ini sebenarnya pelikel atau polisakarida ekstraseluler hasil bentukan bakteri Acetobacter xylinum yang terakumulasi kemudian mengapung di permukaan media cair (Rahayu dan Rahayu, 2007; Chen et al., 2009; Shi et al., 2012). Wijayanti dkk., (2016) menyatakan tahapan terbentuknya lapisan pelikel nata diawali dengan proses hidrolisis sumber karbon yang berasal dari sukrosa atau pati menghasilkan glukosa dan fruktosa menggunakan enzim sukrase dan enzim invertase. Glukosa atau fruktosa yang terbentuk selanjutnya diubah menjadi selulosa oleh Acetobacter xylinum. Pembentukan selulosa dari glukosa diawali dengan adanya proses fosforilasi di dalam glukosa menjadi glukosa-6-fosfat yang dikatilis enzim glukokinase. Selanjutnya mengalami proses isomerasi yang dikatilis enzim fosfoglukomutase menjadi glukosa-1fosfat. Setelah itu terjadi pembentukan UDPglukosa yang dibantu oleh enzim UDPG firofosforilase serta pembentukan benang selulosa di luar sel dengan bantuan enzim selulosa sintase (Anas et al., 2012; Sunagawa et al., 2013).

Sumber karbon yang umum dipakai dalam pembuatan nata de coco yaitu sukrosa (gula pasir) karena mudah untuk mendapatkannya tetapi harganya mahal. Pemakaian sukrosa dalam pembuatan produk ini berdampak terhadap harga jual produk, bila bahan bakunya mahal maka produk akan dijual dengan harga mahal juga. Alternatif lain pengganti sukrosa dalam pembuatan nata de coco yaitu molase. Bahan inihasil samping pengolahan tebu menjadi gula pasir. Kandungan gula di dalam molase terdiri atas sukrosa 35\%, glukosa 7\%, fruktosa 9\%, karbohidrat lain 4\%. (Kusmiati et al., 2007). Tingginya kandungan gula total di dalam molase mempunyai peluang bisa dimanfaatkan sebagai sumber karbon alternatif dalam pembuatan nata de coco.

Berdasarkan uraian di atas perlu dilakukan penelitian mengenai pemanfaatan molase sebagai sumber karbon alternatif dalam pembuatan nata de coco. Tujuan penelitian ini untuk mengetahui seberapa besar peranan molase sebagai sumber karbon alternatif dalam pembentukan nata de coco serta pengaruhnya terhadap karakteristik produk ini.

\section{METODE PELAKSANAAN}

\section{Bahan}

Bahan yang digunakan dalam penelitian yaitu air kelapa dari buah kelapa varietas Sawarna (DSA) diperoleh dari Desa Dampit Kabupaten Malang, molase diperoleh dari Pabrik Gula Kebon Agung di Kabupaten Malang, ammonium sulfat food grade, asam asetat glacial, aquadestdiperoleh dari toko kimia Makmur Sejati di Kota Malang, sukrosa merk gulaku diperoleh dari toko swalayan di Kota Malang, starter Acetobacter xylinum diperoleh dari 
Laboratorium Rekayasa Proses Universitas Tribhuwana Tunggadewi.

Alat

Peralatan yang digunakan yaitu panci dari bahan stainless stell, bak fermentasi dengan spesifikasi dari bahan plastik transparan, merk Maspion, ukuran bak panjang $12 \mathrm{~cm}$, lebar $12 \mathrm{~cm}$ dan tinggi bak $15 \mathrm{~cm}$, jangka sorong krisbow vernier caliper (KW0600071), gelas ukur plastik ukuran 100 ml merk maspion, , timbangan analitik shimadzu, timbangan ukuran $100 \mathrm{~kg}$, spektrofotometri Vis (Visible), kuvetmerk UV-Vis, kertaslakmus merk Johnson, gelasukur $100 \mathrm{ml}$ merk pyrex, pipet volume $10 \mathrm{ml}$ class A merk supertek.

\section{RancanganPenelitian}

Rancangan penelitian yang digunakan adalah Rancangan Acak Tersarang (RAT) yang disusun secara faktorial, faktornya ada dua yaitu factor pertama sumber karbon (C) terdiri dua level $\mathrm{C} 1=$ gula pasir, $\mathrm{C} 2=$ molase sedangkan factor kedua konsentrasi sumber karbon $(\mathrm{K})$ terdiri tiga level $\mathrm{K} 1=$ $1 \%, \mathrm{~K} 2=2 \%, \mathrm{~K} 3=3 \%$. Sumber karbon merupakan faktor utama sedangkan konsentrasi sumber karbon tersarang pada faktor utama (sumber karbon), setiap perlakuan diulang sebanyak 4 kali. Penentuan perlakuan terbaik dihitung menggunakan rumus indeks efektifitas berdasarkan parameter ketebalan nata, bobot nata, warna dan kadar serat.

\section{Pengamatan}

Media fermentasi nata diinkubasi selama 12 hari pada suhu ruang.Pemanenan dilakukan setelah 12 hari masa inkubasi tercapai. Parameter yang diamati meliputi : ketebalan nata (Gayathry, 2015), bobot nata (Gayathry, 2015), warna (AOAC, 2002) dan kadar serat (Barry dan Cleary, 2014).

\section{Analisa Data}

Data hasil penelitian dianalisa menggunakan Analysis of Varians (ANOVA), apabila hasil ANOVA menunjukkan beda nyata dilanjutkan dengan uji lanjut menggunakan uji Beda Nyata Terkecil (BNT) dengan $\alpha=5 \%$ (Hanafiah, 2012; Kumalaningsih, 2012).

\section{HASIL DAN PEMBAHASAN}

Pemberian beberapa jenis sumber karbon berpengaruh terhadap karakteristik nata de coco yang dihasilkan.Karakteristik nata de coco yang diamati adalah ketebalan nata $(\mathrm{cm})$, bobot nata (gram), serat kasar $(\%)$ dan warna.

\section{Ketebalan Nata}

Hasil penelitian ditunjukkan sumber karbon dari molase memberikan ketebalan nata yang tidak berbeda nyata dengan nata yang dihasilkan dari sumber karbon gula pasir. Hal tersebut bisa dilihat pada tabel di bawah ini.

Tabel 1. Rata-rata ketebalan nata de coco pengaruh pemberian sumber karbon yang berbeda

\begin{tabular}{cc}
\hline Sumber Karbon & Ketebalan Nata $(\mathbf{c m})$ \\
\hline Gula Pasir & 1,51 \\
Molase & 1,85 \\
\hline
\end{tabular}

Pada tabel 1 rata-rata ketebalan nata de coco dari sumber karbon molase adalah $1,85 \mathrm{~cm}$ dan rata-rata ketebalan nata de coco dari sumber karbon gula pasir adalah 1,51 cm. Sumber karbon yang berbeda tidak berpengaruh terhadap parameter ketebalan nata.

Tabel 2. Rata-rata ketebalan nata de coco pengaruh pemberian sumber karbon dan konsentrasi yang berbeda

\begin{tabular}{cc}
\hline Sumber Karbon dan Konsentrasi & Ketebalan Nata (cm) \\
\hline Gula Pasir 1\% & 1,28 \\
Gula Pasir 2\% & 1,55 \\
Gula Pasir 3\% & 1,70 \\
Molase 1\% & 1,65 \\
\hline
\end{tabular}




\begin{tabular}{lc}
\hline Molase $2 \%$ & 1,83 \\
Molase 3\% & 1,98 \\
\hline
\end{tabular}

Pada tabel 2 konsentrasi sumber karbon tidak berpengaruh nyata terhadap ketebalan nata de coco. Semakin tinggi konsentrasi sumber karbon semakin bertambah ketebalan nata de coco namun hasilnya tidak berbeda nyata antar perlakuan. Hal ini dikarenakan pada saat penambahan konsentrasi gula atau molase telah optimum untuk pertumbuhan bakteri Acetobacter xylinum.

Tabel 1 dan 2 diperlihatkan ketebalan nata de coco tidak dipengaruhi oleh sumber karbon yang berbeda dengan konsentrasi yang berbeda pula. Molase sebagai sumber karbon alternatif berkemampuan untuk diubah menjadi selulosa dan hasilnya tidak berbeda dengan gula pasir. Hal ini karena molase mengandung kadar gula sekitar 50$60 \%$, sejumlah amino dan mineral (Pertiwi et al., 2009). Kadar gula yang cukup tinggi pada molase bisa menjadi sumber karbon dalam media fermentasi pembuatan nata de coco.
Bakteri Acetobacter xylinum dapat hidup dan berkembang pada media yang mengandung gula. Gula digunakan dalam pembentukan pelikel nata. Gula mengandung sukrosa yang berfungsi sebagai sumber karbon untuk pertumbuhan bakteri (Nurhayati, 2006). Selain gula, molase juga mengandung sukrosa. Pangesti et al. (2012) menyatakan bahwa kandungan sukrosa di dalam molase adalah sekitar 40-60\%, glukosa dan fruktosa dalam konsentrasi yang lebih rendah. Hal inilah yang menyebabkan bakteri Acetobacter xylinum dapat hidup dan berkembang dalam media yang mengandung molase sebagai pengganti gula pasir sehingga ketebalan nata yang dihasilkan tidak berbeda dengan nata dari media yang mengandung gula pasir.

\section{Bobot Nata (gram)}

Hasil perlakuan sumber karbon yang berbeda ditunjukkan bobot nata de coco berbeda nyata antar perlakuan.Hal tersebut dapat dilihat pada tabel $3 a$ dan $3 b$.

Tabel 3a. Rata-rata bobot nata de coco pengaruh pemberian sumber karbon yang berbeda

\begin{tabular}{cr}
\hline Sumber Karbon & Bobot Nata \\
\hline Gula Pasir & 202,5 \\
Molase & 253,33 \\
BNT 1\% & 10,81 \\
\hline
\end{tabular}

Keterangan : Angka-angka yang diikuti huruf yang sama pada kolom yang sama menunukkan tidak beda nyata pada taraf BNT $1 \%$

Tabel 3b. Rata-rata bobot nata de coco pengaruh pemberian sumber karbon dan konsentrasi yang berbeda

\begin{tabular}{cc}
\hline $\begin{array}{c}\text { Sumber Karbon dan } \\
\text { Konsentrasi }\end{array}$ & Bobot Nata (gram) \\
\hline Gula Pasir 1\% & $167,50 \mathrm{e}$ \\
Gula Pasir 2\% & $205,00 \mathrm{~d}$ \\
Gula Pasir 3\% & $235,50 \mathrm{c}$ \\
Molase 1\% & $232,50 \mathrm{c}$ \\
Molase 2\% & $252,50 \mathrm{~b}$ \\
Molase 3\% & $275,00 \mathrm{a}$ \\
BNT 1\% & 10,81 \\
\hline
\end{tabular}

Keterangan : Angka-angka yang diikuti huruf yang sama pada kolom yang sama menunukkan tidak beda nyata pada taraf BNT $1 \%$

Tabel 3a dan 3b diperlihatkan bobot nata de coco.Bobot nata de coco pengaruh sumber karbon berbeda terhadap dengan sumber karbon molase lebih berat 
dibandingkan bobot nata de coco dengan sumber karbon gula pasir.Bobot nata meningkat secara signifikan dengan penambahan konsentrasi sumber karbon.Hal tersebut terjadi pada nata de coco dari sumber karbon gula pasir dan molase.

Penambahan konsentrasi karbon baik dari sumber karbon gula pasir dan molase menunjukkan rata-rata bobot nata de coco yang terus meningkat. Hal ini memperlihatkan adanya penambahan ratarata berat selulosa seiring dengan kenaikan konsentrasi sumber karbon yang digunakan. Adanya peningkatan konsentrasi akan meningkatkan ketersediaan substrat karbon sehingga bakteri memperoleh nutrisi yang lebih baik untuk pembentukan selulosa.

Gula pasir merupakan sumber karbon yang umum digunakan dalam pembuatan nata de coco.Penggunaan gula pasir selama ini memberikan hasil nata de coco yang baik namun harga gula pasir tidak konstan dan ada kecenderungan terus naik menyebabkan biaya produksi yang terus bertambah.
Molase merupakan hasil sampng industri gula tebu yang masih mengandung glukosa, mineral, protein dan vitamin yang sangat dibutuhkan dalam proses fermentasi (Kusmiati dkk., 2007). Molase dapat digunakan sebagai bahan alternatif pengganti gula sebagai sumber karbon dalam media fermentasi.

Dari tabel di atas tampak bobot nata de coco dengan sumber karbon molase lebih berat dari nata de coco dengan sumber karbon gula pasir. Artinya nata de coco dari sumber karbon molase dapat bersaing dengan nata de coco dari gula pasir sehingga pemanfaatan molase sebagai penyedia glukosa dalam media fermentasi bisa dikembangkan dalam industri pembuatan nata de coco.

\section{Serat Kasar Nata}

Hasil perlakuan sumber karbon berbeda ditunjukkan serat kasar nata de coco berbeda nyata antar perlakuan. Hal tersebut dapat dilihat pada tabel $4 \mathrm{a}$ dan $4 \mathrm{~b}$.

Tabel 4a. Rata-rata serat kasar nata de coco pengaruh pemberian sumber karbon yang berbeda

\begin{tabular}{cc}
\hline Sumber Karbon & Serat Kasar Nata (\%) \\
\hline Gula Pasir & $2,27 \mathrm{a}$ \\
Molase & $2,82 \mathrm{~b}$ \\
BNT 1\% & 0,078 \\
\hline
\end{tabular}

Keterangan : Angka-angka yang diikuti huruf yang sama pada kolom yang sama menunukkan tidak beda nyata pada taraf BNT $1 \%$

Tabel 4b. Rata-rata serat kasar nata de coco pengaruh pemberian sumber karbon dan konsentrasi yang berbeda

\begin{tabular}{cc}
\hline Sumber Karbon dan Konsentrasi & Serat Kasar Nata (\%) \\
\hline Gula Pasir 1\% & $2,09 \mathrm{a}$ \\
Gula Pasir 2\% & $2,21 \mathrm{~b}$ \\
Gula Pasir 3\% & $2,50 \mathrm{c}$ \\
Molase 1\% & $2,68 \mathrm{~d}$ \\
Molase 2\% & $2,84 \mathrm{e}$ \\
Molase 3\% & $2,95 \mathrm{f}$ \\
BNT 1\% & 0,078 \\
\hline
\end{tabular}

Keterangan : Angka-angka yang diikuti huruf yang sama pada kolom yang sama menunukkan tidak beda nyata pada taraf BNT $1 \%$

Tabel $4 \mathrm{a}$ dan $4 \mathrm{~b}$ ditunjukkan kadar serat nata de coco dengan sumber karbon molase lebih baik daripada kadar serat nata de coco dengan sumber karbon gula pasir.
Molase sebagai sumber karbon dapat menyediakan nutrisi yang cukup bagi pertumbuhan bakteri Acetobacter xylinum dalam media fermentasi. 
Nata de coco adalah olahan pangan yang dihasilkan dari proses fermentasi oleh bakteri Acetobacter xylinum yang menghasilkan lapisan tipis terapunf diatasnya. Lapisan ini merupakan hasil perubahan sukrosa di dalam sumber karbon menjadi selulosa secara ekstraseluler sehingga sel-sel bakteri akan terperangkap dalam fiber selulosa (Nurhayati, 2006) dan fiber ini mempunyai bentuk partikel yang tebal.

Peningkatan kadar serat seiring dengan peningkatan konsentrasi sumber karbon yang ditambahkan. Sumber karbon yang mengandung kadar sukrosa yang terus meningkat akan menambah kadar nutrisi yang dibutuhkan bakteri Acetobacter xylinum dalam mengubah sebagian glukosa menjadi selulosa sehingga serat kasar yang terbentuk juga akan meningkat. Santosa dkk. (2019) menyatakan serat kasar yang terbentuk adalah hasil perombakan gula pada media fermentasi oleh aktivitas Acetobacter xylinum.
Berdasarkan

analisa ragam menunjukkan molase sebagai sumber karbon mampu menyediakan nutrisi bagi pertumbuhan Bakteri Acetobacter xylinum dalam proses pembentukan pelikel nata sehingga molase dapat digunkan sebagi sumber karbon alternative dalam media fermentasi.

\section{Warna}

Nilai warna berada pada kisaran 0-100 dengan 0 untuk warna yang sangat gelap dan 100 untuk warna yang cenderung terang/putih (Pomeranz dan Meloans, 2004). Hasil sidik ragam ditunjukkan bahwa tingkat kecerahan nata de coco dengan sumber karbon berbeda adalah rata-rata tingkat kecerahan tertinggi ada pada nata de coco dengan sumber karbon gula pasir pada semua konsentrasi sedangkan rata-rata tingkat kecerahan rendah terdapat pada nata de coco dengan sumber karbon molase pada berbagai konsentrasi.Hal tersebut dapat dilihat pada tabel di bawah ini.

Tabel 5. Rata-rata tingkat intensitas warna nata de coco hasil perlakuan sumber karbon dan konsentrasi yang berbeda

\begin{tabular}{ccrrrl}
\hline Sumber Karbon & Perlakuan & \multicolumn{1}{c}{$\mathbf{L}$} & \multicolumn{1}{c}{$\mathbf{a}^{*}$} & \multicolumn{1}{c}{$\mathbf{b}^{*}$} & Deskripsi Warna \\
\hline & $\mathrm{K}_{1} \mathrm{U}_{1}$ & 38,8 & 7,8 & 1,1 & Putih Keruh \\
& $\mathrm{K}_{1} \mathrm{U}_{2}$ & 36,2 & 7,7 & 0,7 & Putih Keruh \\
& $\mathrm{K}_{1} \mathrm{U}_{3}$ & 32,7 & 9 & 2,2 & Putih Keruh \\
& $\mathrm{K}_{1} \mathrm{U}_{4}$ & 30,5 & 7,9 & 1 & Putih Keruh \\
& $\mathrm{K}_{2} \mathrm{U}_{1}$ & 34 & 8,7 & 1,6 & Putih Keruh \\
Gula Pasir & $\mathrm{K}_{2} \mathrm{U}_{2}$ & 34,4 & 8,1 & 2 & Putih Keruh \\
& $\mathrm{K}_{2} \mathrm{U}_{3}$ & 33,4 & 9,1 & 1,1 & Putih Keruh \\
& $\mathrm{K}_{2} \mathrm{U}_{4}$ & 33 & 9 & 1,4 & Putih Keruh \\
& $\mathrm{K}_{3} \mathrm{U}_{1}$ & 33,6 & 10,1 & 1 & Putih Keruh \\
& $\mathrm{K}_{3} \mathrm{U}_{2}$ & 35,1 & 9,6 & 0,7 & Putih Keruh \\
& $\mathrm{K}_{3} \mathrm{U}_{3}$ & 38,1 & 10,3 & 0,4 & Putih Keruh \\
& $\mathrm{K}_{3} \mathrm{U}_{4}$ & 36,2 & 9,4 & 0,6 & Putih Keruh \\
\hline \multirow{6}{*}{ Molase } & $\mathrm{K}_{1} \mathrm{U}_{1}$ & 27,1 & 9,7 & 8,8 & Keruh (Coklat) \\
& $\mathrm{K}_{1} \mathrm{U}_{2}$ & 28,9 & 9,5 & 9,5 & Keruh (Coklat) \\
& $\mathrm{K}_{1} \mathrm{U}_{3}$ & 27 & 8,8 & 6,4 & Keruh (Coklat) \\
& $\mathrm{K}_{1} \mathrm{U}_{4}$ & 27,7 & 8,7 & 7,3 & Keruh (Coklat) \\
& $\mathrm{K}_{2} \mathrm{U}_{1}$ & 26,6 & 8,1 & 7 & Keruh (Coklat) \\
& $\mathrm{K}_{2} \mathrm{U}_{2}$ & 26,8 & 10,3 & 7,1 & Keruh (Coklat) \\
& $\mathrm{K}_{2} \mathrm{U}_{3}$ & 26,1 & 9,4 & 6,7 & Keruh (Coklat) \\
& $\mathrm{K}_{2} \mathrm{U}_{4}$ & 26,3 & 8,9 & 6,9 & Keruh (Coklat) \\
& $\mathrm{K}_{3} \mathrm{U}_{1}$ & 23,8 & 9,7 & 6,4 & Keruh (Coklat) \\
& $\mathrm{K}_{3} \mathrm{U}_{2}$ & 26,8 & 10,6 & 6,4 & Keruh (Coklat) \\
& $\mathrm{K}_{3} \mathrm{U}_{3}$ & 26,2 & 9,2 & 6,5 & Keruh (Coklat) \\
& $\mathrm{K}_{3} \mathrm{U}_{4}$ & 24,7 & 9,6 & 6,5 & Keruh (Coklat) \\
\hline
\end{tabular}


Tabel 5 ditunjukkan rata-rata tingkat kecerahan nata de coco dengan sumber karbon gula pasir lebih tinggi daripada nata de coco dengan sumber karbon molase. Semakin tinggi konsentrasi molase semakin rendah tingkat kecerahan nata de coco yang dihasilkan.Hal ini dikarenakan molase adalah hasil samping industri gula tebu berupa sisa sirup yang berwarna agak hitam. Warna dasar molase ini berpengaruh terhadap rata-rata tingkat kecerahan nata de coco yang dihasilkan.

Pemanfaatan molase sebagai sumber karbon alternative dalam media fermentasi pembuatan nata de coco dapat diterapkan degan baik.Kualitas nata de coco dengan sumber karbon molase tidak berbeda dengan kualitas nata de coco dari sumber karbon gula pasir.Namun kekurangan nata de coco dengan sumber karbon molase ada pada warna yang kurang menarik dan hal ini dapat diatasi dengan teknologi tertentu.

\section{KESIMPULAN}

Molase dapat digunakan sebagai sumber karbon alternatif dalam pembuatan nata de coco. Konsentrasi molase yang menghasilkan nata de coco berkualitas yaitu $3 \%$ dengan ketebalan $1,98 \mathrm{~cm}$, bobot 275 gram dan serat kasar 2,95\%. Namun warna nata de coco yang dihasilkan keruh coklat. Dengan demikian molase dapat digunakan sebagai sumber karbon pengganti gula pasir dalam pembuatan nata de coco.

\section{DAFTAR PUSTAKA}

Anas, A.K., Salma, A. \& Nugroho, F. (2012). Pengaruh variasi massa umbi ganyong (Canna edulis) pada pembuatan dan karakterisasi plastik biodegradable ramah lingkungan berbahan dasar umbi ganyong. Prosiding Seminar Nasional Penelitian, Pendidikan dan Penerapan MIPA. Fakultas MIPA. Universitas Negeri Yogyakarta.
AOAC. (2002). Official methods of analysis of the association of official analytical chemists. Publisher by the Association of Official Analytical Chemists PO BOX 540 Benjamin Franklin Station Washington DC 20044.

Backdahl, H., Risberg, B., \& Gatenholm, P. (2011). Observation on bacterial cellulose tube formation for application as vascular graft. Journal of Materials Science and Engineering, (C31), 14-21.

Barry, V., \& Mc Cleary. (2014). Modification to AOAC official mehods 2009.01 and 2011.25 to allow for minor overestimation of low moleculer weight soluble dietary fiber in samples containing starch. Journal of AOAC International, 97(3), 896-901.

Bhantumnavin, W., Wanichapichart, P., Taweepreeda, W., Sirijarukula, S., \& Paosawatyanyong, B. (2016). Surface modification of bacterial cellulose membrane by oxygen plasma treatment. Journal of Surface and Coatings Technology, (306), 272278.

Chen, S., Zou, Y., Yan, Z., Shen, W., Shi, S., Zhang, X., \& Wang, H. (2009). Carboxymethylated bacterial cellulose for copper and lead ion removal. Journal of Hazardous Materials, (161), 1355 - 1359.

Gayathry, G. (2015). Production of nata de coco a natural dietary fibre product from mature coconut water using Gluconacetobacter xylinum. International Journal Food Fermentation Technology, 5(2), 231235.

Hanafiah, K.A. (2012). Rancangan percobaan (teori dan aplikasi). Jakarta. Rajawali Press.

Hidayat, N., Padaga, M.C., \& Suhartini, S. (2006). Mikrobiologi industri. Yogyakarta. Penerbit Andi: 121 125. 
Hirayama, K., Okitsu, T., Teramae, H., Kiriya, D., Onoe, H., \& Takeuchi, S. (2013). Cellular building unit integrated with microstrand shaped bacterial cellulose. Journal of Biomaterials, (34), 2421 - 2427.

Iskandar, Z., Mulyati, M., Fathanah, S., Sari, I.U., \& Juchairawati. (2010). Pembuatan film selulosa dari nata de pina. Jurnal Rekayasa Kimia dan Lingkungan, 7(3), 105-111.

Jiazhi, Y., Chenggang, Z., Xiaoli, L., Junwei, Y., Dongping, S., \& Weihua, T. (2011). Preparation of high quality indium tin oxide film on a microbial cellulose membrane using radio frequency magnetron sputtering. Chinese Journal of Chemical Engineering, 19(2), 179-184.

Jung, H.I., Jeong, J.H., Lee, O.M., Park, G.T., Kim, K.K., Park, H.C., Lee, S.M., Kim, Y.G., \& Son, H.J. (2010). Influence of glycerol on production and structural physical properties of cellulose from Acetobacter sp. V6 cultured in shake flasks. Journal of Bioresource Technology, (101), 3602-3608.

Kumalaningsih, S. (2012). Metodologi penelitian (kupas tuntas cara mencapai tujuan). Malang. UB Press: $92-100$.

Kusmiati, Tamat, S.R., Nuswantara, S., \& Isnaini, N. (2007). Produksi dan penetapan kadar $\beta$-glukandari tiga galur saccharomyces cerevisiae dalam media mengandung molase. Jurnal Ilmu Kefarmasian Indonesia, 1(5), 7-16.

Lin, W.C., Lien, C.C., Yeh, H.J., Yu, C.M., \& Hsu, S.H. (2013). Bacterial cellulose and bacterial cellulosechitosan membranes for wound dressing applications. Journal of Carbohydrat Polymers, (94), 603611.

Martins, I.M.G., Magina, S.P., Oliveira, L., Freire, C.S.R., Silvestre, A.J.D., Neto, C.P., \& Gandini, A. (2009). New biocomposites based on thermoplastic starch and bacterial cellulose. Journal of Composites Science and Technology (69), 21632168.

Nurhayati, N. (2006). Kajian pengaruh kadar gula dan lama fermentasi terhadap kualitas nata de soya. Jurnal Matematika, Sains dan Teknologi, 7(1), 40-47.

Pangesti, N.W.I., Pangastuti, A., \& Retnaningtyas, E. (2012). Pengaruh penambahan molase pada produksi enzim xilanase oleh fungi aspergillus niger dengan substrat jerami padi. Jurnal Bioteknologi, 9(2), 41-48.

Pertiwi, A.A.P., Pardoyo, \& Subagio, A. (2009). Pengaruh temperatur dan waktu karbonasi pada sintesis porous carbon berbahan dasar molase. Jurnal Kimia Sains dan Aplikasi, 3 (12), 93-97.

Pratomo, H., \& Rohaeti, E. (2011). Bioplastik nata de cassava sebagai bahan edible film ramah lingkungan. Jurnal Penelitian Saintek, 16(2), 172180.

Pomeranz \& Meloan. (2004). Food analysis: teory and practice. The AVI Publishing.Co, Inc, Wesport. Connecticut: $30-43$.

Rahayu, T., \& Rahayu, T. (2007). Optimasi fermentasi cairan kopi dengan inokulan kultur kombucha (kombucha coffe). Jurnal Penelitian Sains dan Teknologi, 8(1), 15-28.

Santosa, B., Ahmadi, Kgs., \& Taeque, D. (2012). Dextrin concentration and carboxy methyl cellulosa $(\mathrm{cmc})$ in making of fiber-rich instant baverage from nata de coco. International Journal of Science and Technology, 1(1), 6-11.

Santosa, B., Tantalu, L., \& Sugiarti, U. (2019). Penambahan ekstrak kulit buah naga pada pengembangan produk nata de coco berantioksidan. Jurnal Teknologi Pangan, 10(1), 1 8.

Shi, Q., Yang Sun, L.J., Zhang, H., Chen, L., Chen, B., Yang, H., \& Wang, Z. 
(2012). The osteogenesis of bacterial cellulose scaffold loaded with bone morphogenetic. Journal of Biomaterials, (33), 6644-6649.

Sunagawa, N., Fujiwara, T., Yoda, T., Kawano, S., Satoh, Y., Yao, M., Tajima, K., \& Dairi, T. (2013). Cellulose complementing factor (ccp) is a new member of the cellulose synthase complex (terminal complex) in acetobacter xylinum. Journal of Bioscience and Bioengineering, 115(6), 607-612.

Syamsu, K., Haditjaroko, L., Pradikta, G.I., \& Rotiadi, H. (2014). Campuran pulp tandan kosong kelapa sawit dan selulosa mikrobial nata de cassava dalam pembuatan kertas. Jurnal Ilmu Pertanian Indonesia, 19(1), 14-21.

Wijayanti, E., Hastuti, U.S., \& Rohman, F. (2016). Pengaruh macam gula terhadap tebal dan berat nata dari jeruk pamelo (Citrus maxima (Burn. F.) varietas nambangan. Prosiding Seminar Nasional II Tahun 2016, Kerjasama Program Studi Fakultas Keguruan Dan Ilmu Pendidikan Dengan Pusat Studi Lingkungan Dan Kependudukan Universitas Muhammadiyah Malang (hal 326332). 